\title{
Knowledge and Attitude of Medical Students towards the Corona Virus-19 Pandemic Situation
}

\author{
Ahmad $\mathrm{M}^{1}$, Rahman $\mathrm{FN}^{2}$, Wahab $\mathrm{MA}^{3}$, Anwar ZF ${ }^{4}$, Rahman J5 \\ DOI:https://doi.org/10.3329/jafmc.v16i2.55292
}

\begin{abstract}
Background: COVID-19 has created a worldwide health emergency status and super spreading in the community of Bangladeshi population causing morbidity and mortality.

Objectives: To find out the knowledge and attitude of medical students towards the Covid-19 pandemic during the lockdown situation.

Methodology: This online cross sectional study was conducted from 1st to 31st May 2020 during the lockdown period in Bangladesh. Sample collection proforma was uploaded on the Google forms and links were shared on different social platforms. Data was analyzed by SPSS IBM version 22.00 .
\end{abstract}

Results: A total of 269 responses were obtained. The majority of the participants $167(62.1 \%)$ were female and 102 (44.6\%) belonged to an age group of 20-24 years. Most of the 91(33.8\%) participants were 4th years students followed by $87(32.3 \%)$ from 3rd year. Majority of participants 230(85.5\%) believe COVID-19 affect all age group, 187(69.5\%) thinks that it affect the elder people seriously, $115(42.8 \%)$ thinks specific treatment may be available for COVID-19, 184(68.4\%) says COVID-19 infection is preventable, 242(90\%) opted for government lockdown and 225(83.6\%) believed physical distancing is needed to prevent spread of this disease. Most of the participants 232(86.3\%) complained about absence of diagnostic facilities in their neighboring area, 231(85.9\%) thought common sign symptoms included dry cough, fever, fatigue and difficulty in breathing, most $234(87 \%)$ of the respondents thinks early supportive and symptomatic treatment can be helpful in cure of COVID-19 infection, 230(85.5\%) gave positive opinion about isolation from the people who are infected with the COVID-19 virus is an effective way to reduce the spread of the virus. Regarding 14 days quarantine period 222(82.5\%) give positive answer, 169(62.8\%) thought COVID-19 would affect world economy badly, $172(63.9 \% 0$ thought common people are facing problem to collect daily needs, 184(68.4\%) gave positive response that COVID-19 pandemic affects mental health of population, $93(34.6 \%)$ thought the situation may be controlled soon, majority $97(36.1 \%)$ answered they may be satisfied by current practices and initiatives taken by the government, almost all participants 265(97.4\%) appreciated the efforts of healthcare providers for their society, 262(97.4\%) of the participants thought there is need of more general awareness about COVID-19 pandemic and 260(96.7\%) recommended procedure for repeated washing hands.

Conclusion: An increasing awareness is needed amongst the local population regarding COVID-19 is required. It will lend hands in preventing spread of COVID-19 with minimal secondary transmission. More elaborate survey studies are required in future that can provide supportive data in developing and implementing public health policies regarding COVID-19 pandemic in our country.

Key-words: COVID-19, knowledge, Attitude, Medical students.

\section{Introduction}

Bangladesh is one of the top 20 countries in terms of confirmed cases of COVID-19, with a positive case rate of $19.09 \%-22.91 \%$ as of June 1, 2020. In Bangladesh, the first confirmed case was reported on 8 March 2020. Infection stayed low until the end of March but saw a steep rise in April 20201. However, a number of questions arises regarding the actual number of cases and the lack of testing facilities ${ }^{2}$ and people show concerns about government's ability for effective response to this pandemic ${ }^{3}$. Reports of different newspaper states COVID-19 is a challenge for the developing economy of Bangladesh and its residents at abroad, which mainly depends on ready-made garments exports and remittances ${ }^{4,5}$. Bangladesh authority did not impose countrywide lockdown during early period ${ }^{6}$. Newspaper and social media along with government news briefing helped a lot to improve individual awareness and thereby alleviate unnecessary fears and social stigmas? ${ }^{7}$.

The history of pandemic by Spanish flu with H1N1 influenza virus in 1918 affected as many as 500 million people across the world with a massive rise in death toll shooting from 17 to 50 million8. A similar situation was faced by the spread of H1N1 Swine flu during 2009-2010. In which around 6.8 billion people were affected and nearly 5 million people died. In recent times, COVID-19 outbreak is accounted as a global issue with a health emergency like situation. The viral outbreak was first reported in Wuhan City, of Hubei province in the last month of year 2019 and Novel corona virus was identified as the responsible agent. Later the World Health

1. Col Mushtaq Ahmad, MBBS, DFM, MCPS, FRSPH, Professor \& Head, Department of Forensic Medicine, Armed Forces Medical College, Dhaka (E-mail: mushtaq863@yahoo.com) 2. Dr Farial Naima Rahman, MBBS, DMU, Lecturer, Department of Forensic Medicine, Armed Forces Medical College, Dhaka 3. Lt Col Md Abdul Wahab, MBBS, MD, Associate Professor, Dept of Biochemistry, Armed Forces Medical College, Dhaka 4. Dr Zian Fariba Anwar, MBBS, MRCP, MRCP (UK) Lecturer, Department of Forensic Medicine, Armed Forces Medical College, Dhaka 5. Dr Jamiur Rahman, MBBS, MRCP(UK), Lecturer, Department of Pharmacology, Armed Forces Medical College, Dhaka. 
Organization named it as COVID-19. The symptoms coincides with previous outbreaks of severe acute respiratory syndrome (SARS) and Middle East respiratory syndrome (MERS) ${ }^{9,10}$.

\section{Materials and Methods}

This cross sectional online study was conducted from 1st to 31st May 2020 during the lockdown period in Bangladesh. At that time physical interaction for questionnaire distribution and filling was not possible to have the community based survey. For the purpose of sample collection, a two pages questionnaire was generated by consulting the recent published studies ${ }^{11,12}$.

Further, sample collection proforma was uploaded on the Google forms and links were shared on different social platforms like WhatsApp, FaceBook, Linkedln, Twitter etc. Authors have also sought help from their available reliable connections to distribute this sample collection form in order to get maximum response from the volunteer participants. Respondents were students of different medical colleges and they had to respond either in "Yes " or "No" or "May Be" in order to confirm their participation voluntarily. Once approval of voluntary participation was confirmed participants were navigated to the sample collection instrument. Data was analyzed by SPSS IBM version 22.00 .

\section{Results}

A total of 269 responses were obtained. The majority of the participants 167 (62.1\%) were female and 102 (44.6\%) belonged to an age group of 20-24 years. Most of the $91(33.8 \%)$ participants were 4th years students followed by $87(32.3 \%)$ from 3rd year (Table-I).

Table-I: Demographic profile of the participants $(n=269)$

\begin{tabular}{|l|c|c|c|c|c|}
\hline \multirow{2}{*}{$\begin{array}{l}\text { Gender } \\
\text { (n 269) }\end{array}$} & Male & Female & \multicolumn{3}{|c|}{} \\
\cline { 2 - 6 } & $\begin{array}{c}102 \\
(37.9 \%)\end{array}$ & $\begin{array}{c}167 \\
(62.1 \%)\end{array}$ & \multicolumn{3}{|c|}{} \\
\hline \multirow{2}{*}{$\begin{array}{l}\text { Educational } \\
\text { qualification }\end{array}$} & $\mathbf{1}^{\text {st }}$ year & $\mathbf{2}^{\text {nd }}$ year & $3^{\text {rd }}$ year & $\mathbf{4}^{\text {th }}$ year & $\mathbf{5}^{\text {th }}$ year \\
\cline { 2 - 6 } & $23(8.6 \%)$ & $39(14.5 \%)$ & $87(32.3 \%)$ & $91(33.8 \%)$ & $29(10.8 \%)$ \\
\hline \multirow{2}{*}{ Age } & $\mathbf{2 0}$ years & $\mathbf{2 1}$ years & $\mathbf{2 2}$ years & $\mathbf{2 3}$ years & $\mathbf{2 4}$ years \\
\cline { 2 - 6 } & $25(9.3 \%)$ & $37(13.8 \%)$ & $88(32.7 \%)$ & $90(33.5 \%)$ & $29(10.8 \%)$ \\
\hline
\end{tabular}

In this study 230(85.5\%) answered COVID-19 affect all age group, $187(69.5 \%)$ thought that it affect the older people seriously, $115(42.8 \%)$ thinks specific treatment may be available for COVID-19, majority of respondents $184(68.4 \%)$ opted that COVID-19 infection is preventable, 242(90\%) gave positive opinion regarding lockdown and 225(83.6\%) believed physical distancing is helpful to prevent spread of this disease. Most of the participants 232(86.3\%) complained about absence of diagnostic facilities in their neighboring area, 231(85.9\%) thought common sign symptoms included dry cough, fever, fatigue and difficulty in breathing, most $234(87 \%)$ of the respondents thinks early supportive and symptomatic treatment can be helpful in cure of COVID-19 infection, 230(85.5\%) gave positive opinion about isolation from the people who are infected with the COVID-19 virus is an effective way to reduce the spread of the virus. About 14 days self quarantine 222(82.5\%) gave positive answer, 169(62.8\%) thought COVID-19 would affect world economy badly, 172(63.9\%0 thought common people are facing problem to collect daily needs, $184(68.4 \%)$ gave positive response that COVID-19 pandemic affects mental health of population, $93(34.6 \%)$ thought the situation may be controlled soon, majority $97(36.1 \%)$ answered they may be satisfied by current practices and initiatives taken by the government, almost all participants 265(97.4\%) appreciated the roll of the efforts healthcare providing personnel, 262(97.4\%) of the participants thought there is need of more general awareness about COVID-19 pandemic and 260(96.7\%) recommended procedure for repeated washing hands (Table-II).

Table-II: Questionnaire regarding knowledge and attitude of the participants $(n=269)$

\begin{tabular}{|c|c|c|c|c|}
\hline $\begin{array}{l}\text { Question } \\
\text { number }\end{array}$ & Questions & Yes & No & May Be \\
\hline 1 & $\begin{array}{l}\text { Do you think all age group } \\
\text { are affected by COVID-19? }\end{array}$ & $\begin{array}{c}230 \\
(85.5 \%) \\
\end{array}$ & $\begin{array}{c}33 \\
(12.3 \%)\end{array}$ & $6(2.2 \%)$ \\
\hline 2 & $\begin{array}{l}\text { Only elderly people are } \\
\text { seriously affected }\end{array}$ & $\begin{array}{c}187 \\
(69.5 \%) \\
\end{array}$ & $\begin{array}{c}45 \\
(16.7 \%)\end{array}$ & $\begin{array}{c}37 \\
(13.8 \%)\end{array}$ \\
\hline 3 & $\begin{array}{l}\text { Specific treatment is now } \\
\text { available for COVID-19 Virus }\end{array}$ & \begin{tabular}{|c|}
69 \\
$(25.7 \%)$
\end{tabular} & $\begin{array}{c}85 \\
(31.6 \%)\end{array}$ & $\begin{array}{c}115 \\
(42.8 \%)\end{array}$ \\
\hline 4 & $\begin{array}{l}\text { COVID-19 infection is } \\
\text { preventable }\end{array}$ & \begin{tabular}{|c|}
184 \\
$(68.4 \%)$
\end{tabular} & $\begin{array}{c}44 \\
(16.4 \%)\end{array}$ & $\begin{array}{c}41 \\
(15.2 \%)\end{array}$ \\
\hline 5 & $\begin{array}{l}\text { Government has declared } \\
\text { lockdown to avoid the } \\
\text { spread of infection }\end{array}$ & $\begin{array}{l}242 \\
(90 \%)\end{array}$ & --- & $\begin{array}{c}27 \\
(10.0 \%)\end{array}$ \\
\hline 6 & $\begin{array}{l}\text { Keep a distance is helpful to } \\
\text { prevent spread of COVID-19 }\end{array}$ & \begin{tabular}{|c|}
225 \\
$(83.6 \%)$ \\
\end{tabular} & $2(0.7 \%)$ & $\begin{array}{c}42 \\
(15.6 \%) \\
\end{array}$ \\
\hline 7 & $\begin{array}{l}\text { Is there any diagnostic } \\
\text { facilities available in your } \\
\text { neighbouring area? }\end{array}$ & $\begin{array}{c}37 \\
(13.8 \%)\end{array}$ & $\begin{array}{c}232 \\
(86.3 \%)\end{array}$ & --- \\
\hline 8 & $\begin{array}{l}\text { Dry cough, fever, fatigue } \\
\text { and difficulty in breathing } \\
\text { are the main symptoms of } \\
\text { COVID-19 infection }\end{array}$ & $\begin{array}{c}231 \\
(85.9 \%)\end{array}$ & $5(1.9 \%)$ & $\begin{array}{c}33 \\
(12.3 \%)\end{array}$ \\
\hline 9 & $\begin{array}{l}\text { Early supportive and } \\
\text { symptomatic treatment can } \\
\text { be helpful in cure of COVID-19 } \\
\text { infection }\end{array}$ & $\begin{array}{c}234 \\
(87 \%)\end{array}$ & $3(1.1 \%)$ & $\begin{array}{c}32 \\
(11.90 \%)\end{array}$ \\
\hline 10 & $\begin{array}{l}\text { Isolation from the people } \\
\text { who are infected with the } \\
\text { COVID-19 virus is an } \\
\text { effective way to reduce the } \\
\text { spread of the virus. }\end{array}$ & $\begin{array}{c}230 \\
(85.5 \%)\end{array}$ & $2(0.7 \%)$ & $\begin{array}{c}37 \\
(13.8 \%)\end{array}$ \\
\hline 11 & $\begin{array}{l}\text { People who have interaction } \\
\text { with someone having this } \\
\text { infection should be } \\
\text { immediately isolated for } 14 \\
\text { days as an quarantine period. }\end{array}$ & $\begin{array}{c}222 \\
(82.5 \%)\end{array}$ & $7(2.6 \%)$ & $\begin{array}{c}40 \\
(14.9 \%)\end{array}$ \\
\hline 12 & $\begin{array}{l}\text { COVID-19 pandemic affects } \\
\text { the world economy badly }\end{array}$ & $\begin{array}{c}169 \\
(62.8 \%) \\
\end{array}$ & \begin{tabular}{|c|}
60 \\
$(22.3 \%)$ \\
\end{tabular} & $\begin{array}{c}40 \\
(14.87 \%) \\
\end{array}$ \\
\hline 13 & $\begin{array}{l}\text { In prevailing scenario } \\
\text { people are facing trouble in } \\
\text { getting their day to day } \\
\text { basic necessities } \\
\text { (food/rations etc) }\end{array}$ & $\begin{array}{c}172 \\
(63.9 \%)\end{array}$ & $\begin{array}{c}39 \\
(14.5 \%)\end{array}$ & $\begin{array}{c}60 \\
(22.3 \%)\end{array}$ \\
\hline 14 & $\begin{array}{l}\text { COVID-19 pandemic affects } \\
\text { mental health of population } \\
\text { (depression, anxiety, loss of } \\
\text { interest etc.) }\end{array}$ & $\begin{array}{c}184 \\
(68.4 \%)\end{array}$ & $\begin{array}{c}23 \\
(8.6 \%)\end{array}$ & $\begin{array}{c}60 \\
(22.3 \%)\end{array}$ \\
\hline
\end{tabular}


Most 188 (69.9\%) people heard about this disease from news channel, 242 (90\%) thought it is caused by a virus, 201 (74.7\%) opted for wearing masks to prevent the infection and 201 (74.7\%)answered that maintaining personal hygiene can improve mental health (Table-III).

Table-III: Questionnaire with multiple choice answer regarding knowledge and attitude of the participants $(n=269)$

\begin{tabular}{|c|c|}
\hline \multicolumn{2}{|l|}{ From where you heard about this disease? } \\
\hline News Channels & $188(69.9 \%)$ \\
\hline Social Media & $53(19.2 \%)$ \\
\hline Family & $5(1.9 \%)$ \\
\hline Others & $23(8.6 \%)$ \\
\hline \multicolumn{2}{|l|}{ In your opinion, the reason of COVID-19 is } \\
\hline Caused by a virus & $242(90 \%)$ \\
\hline By eating infected food & $5(1.9 \%)$ \\
\hline Public gathering & $10(3.7 \%)$ \\
\hline Poor immunity & $12(4.5 \%)$ \\
\hline \multicolumn{2}{|c|}{$\begin{array}{l}\text { What preventive measures you have taken to avoid or spread } \\
\text { the COVID-19 infection }\end{array}$} \\
\hline Social/physical distancing & $40(14.9 \%)$ \\
\hline Wearing mask & $201(74.7 \%)$ \\
\hline Hand wash for 20 seconds & $28(10.4 \%)$ \\
\hline \multicolumn{2}{|c|}{$\begin{array}{l}\text { Healthy activities adopted by you during quarantine to } \\
\text { improve mental health }\end{array}$} \\
\hline Exercise, yoga and walk & $69(25.7 \%)$ \\
\hline Reading & $72(26.8 \%)$ \\
\hline Cooking & $30(11.2 \%)$ \\
\hline Indoor games & $12(4.5 \%)$ \\
\hline $\begin{array}{l}\text { Avoid junk food, eating fresh fruits and } \\
\text { healthy diet }\end{array}$ & $5(1.9 \%)$ \\
\hline Maintain personal hygiene & $41(15.2 \%)$ \\
\hline Sleep & $40(14.9 \%)$ \\
\hline
\end{tabular}

\section{Dscussion}

This study was targeted for the medical students of 1 st year to 5th year of different medical colleges, who had enough time to go through the questionnaire during lockdown period. Current study indicates that the community is well informed and has good knowledge about the COVID-19. News channels and social media like FaceBook, WhatsApp, Twitter, Viber etc have played a significant role in this regard, to make communities familiar with COVID-19 pandemic ${ }^{11-13}$. However, this study has several limitations i.e. students who are living in village area and has less access to internet facilities or online portals to fill the form could not be taken as research population. Moreover participants needed to have an account to access the questionnaire and dissemination of the sampling instrument only through an online platform. The same problem faced by researcher in previous studies ${ }^{14}$. Majority of the population stated that COVID-19 is transmitted through respiratory droplets, can affect all age groups and elderly people were more prone to develop severe infection which could lead to death ${ }^{15}$. The students were well aware about the signs and symptoms of the COVID-19 infection which included dry cough, fever, fatigue and difficulty in breathing.

Many participants of this study were unsure if COVID-19 infection is preventable and early supportive treatment and isolation of the infected patient is helpful in controlling the spread or not because the study was done in the early stage of COVID-19 infection in our country. For COVID-19 infection no specific treatment available and a large number of the respondents agreed on this point ${ }^{16}$. Quarantine or social distancing is helpful in reducing the number of COVID-19 cases. In the prevailing scenario, the government deemed that lockdown could be a best option which may prove beneficial in controlling the infection and declared countrywide lockdown. Many people showed respect this decision and keep themselves under the lockdown but still there are people who didn't take this health emergency seriously. We often found people are roaming here and there without wearing masks. These people are at high risk to have infection and become a source of spreading COVID-19 infection which may result into a hindrance in achieving the goal i.e. controlling the infection ${ }^{17,18}$.

This survey indicates that a small percentage of the respondents admire government initiatives and practices in order to cope with the current situation while remaining are not satisfied. This is the first time authority have faced such a calamity, so there is lot of mis-communication, lack of proper knowledge and timely decision. This study has shown that the public is facing difficulties while getting basic necessities like food. For this long time lock down is not considered as a solution ${ }^{19}, 20$. It is quite impossible to supply food to millions of people during lockdown only by the government. Other than the capital city, diagnostic facilities in different parts of the country are not easily available. Many people use herbal medicines with strong belief for treatment of COVID-19. An investigation has suggested that cure of H1N1 and SARS through Chinese traditional medicine is well documented, based on human evidence and historical data and such medicine could be an alternative approach to prevent COVID-19 in high risk communities ${ }^{21}$.

COVID-19 pandemic is a challenge to the mental well-being of people. This current global health emergency has badly impacted the psychological health (i.e. depression, anxiety, boredom, frustration etc.) of the individuals. To deal with it many students have adopted healthy activities which include exercise, yoga, playing indoor games, reading, writing, cooking etc ${ }^{22,23}$. Further launching of many new free online courses in this duration of crisis is also an effective way to keep students busy and has opened new doors of learning ${ }^{23}$. The internet bill is very high in our country and there is no subsidy for students or educational institutes like medical colleges or universities. It should be brought under consideration of concerned authorities. Worldwide frontline heroes like doctors, pharmacists, nurses, allied health care professionals and paramedical staff and researchers are working tirelessly to fight against the COVID-19 by putting their lives at risk. People globally 
acknowledge their efforts and struggle ${ }^{24-27}$. Result of this study coincides with previous study done by other researchers ${ }^{28-30}$.

\section{Conclusion}

Present study concludes that people are well informed about COVID-19 however still there is need of awareness amongst masses regarding COVID-19 to counteract the spread. People should rather quarantine themselves in order to prevent infection, catering this as a health emergency by keenly observing precautionary measures. However, to keep a mental and physical balance of health, people should adopt healthy activities during the lockdown.

\section{References}

1. Mustazir H, Alif A. Covid-19: Bangladesh records highest 42 deaths in a day, cases cross 65,000 mark. Dhakatribune.com. 2020 [cited 3rd July 2020].

2. India-Pak-Bangladesh: Official Covid-19 numbers disguise undercounting [Internet]. The Daily Star. 2020 [cited 3rd July 2020].

3. Bangladesh cannot afford to close its garment factories [Internet]. The Economist. 2020 [cited 3rd July 2020].

4. Covid-19 infections are rising fast in Bangladesh, India and Pakistan [Internet]. The Economist. 2020 [cited 3rd July 2020].

5. Hasina S, Verkooijen P. Fighting cyclones and coronavirus: How we evacuated millions during a pandemic. The Guardian. 2020 [cited 3rd July 2020].

6. Covid-19 tracker. Bangladesh Computer Council (BCC). Covid19tracker.gov.bd. 2020 [cited 3rd July 2020]. Available from: http://covid19tracker.gov.bd/

7. Corona.gov.bd. Coronavirus Disease 2019 (COVID-19): Information Bangladesh. Corona.gov.bd. 2020 [cited 3 July 2020]. Available from: https://corona.gov.bd/

8. Arshad A, Afzal S. An update on preventive measures of COVID-19 in Pakistan. Annals of King Edward Medical University. 2020; 26(1):1-2.

9. Sohrabi C, Alsafi Z, O'Neill $N$ et al. World Health Organization declares global emergency: A review of the 2019 novel coronavirus (COVID-19). International Journal of Surgery. 2020; 76:71-6.

10. Lipsitch M, Swerdlow DL, Finelli L. Defining the epidemiology of Covid-19-studies needed. New England Journal of Medicine. 2020; 382:1194-6.

11. Zhong B-L, Luo W, Li H-M et al. Knowledge, attitudes, and practices towards COVID-19 among Chinese residents during the rapid rise period of the COVID-19 outbreak: A quick online cross-sectional survey. International Journal of Biological Sciences. 2020; 16(10):1745-52.

12. Rao ASS, Vazquez JA. Identification of COVID-19 can be quicker through artificial intelligence framework using a mobile phone-based survey in the populations when cities/towns are under quarantine. Infection Control \& Hospital Epidemiology. 2020; 41(7):826-30.

13. La V-P, Pham T-H, Ho M-T et al. Policy Response, Social Media and Science Journalism for the Sustainability of the Public Health System Amid the COVID-19 Outbreak: The Vietnam Lessons. Sustainability. 2020; 12(7):29-31.

14. Geldsetzer P. Knowledge and Perceptions of COVID-19 among the General Public in the United States and the United Kingdom: A Cross-sectional Online Survey. Ann Intern Med. 2020:M20-0912.

15. Guo Y-R, Cao Q-D, Hong Z-S et al. The origin, transmission and clinical therapies on coronavirus disease 2019 (COVID-19) outbreak-an update on the status. Mil Med Res. 2020; 7(1):11.

16. Adhikari SP, Meng S, Wu Y-Jet al. Epidemiology, causes, clinical manifestation and diagnosis, prevention and control of coronavirus disease (COVID-19) during the early outbreak period: A scoping review. Infectious Diseases of Poverty. 2020; 9(1):1-12.

17. Wilder-Smith A, Freedman D. Isolation, quarantine, social distancing and community containment: Pivotal role for old-style public health measures in the novel coronavirus (2019-nCoV) outbreak. J Travel Med. 2020; 27(2):taaa020.

18. Watkins J. Preventing a covid-19 pandemic. British Medical Journal. 2020; 368:m810.

19. Hina $H$, Qayyum A. Effect of financial crisis on sustainable growth: Empirical evidence from Pakistan. Journal of the Asia Pacific Economy. 2019; 24(1):143-64.

20. Remuzzi A, Remuzzi G. COVID-19 and Italy: What next? The Lancet. 2020:1225-8.

21. Luo H, Tang Q-I, Shang Y-x et al. Can Chinese medicine be used for prevention of corona virus disease 2019 (COVID-19)? A review of historical classics, research evidence and current prevention programs. Chinese Journal of Integrative Medicine. 2020; 26(4):243-50.

22. Wang $\mathrm{C}$, Pan R, Wan $\mathrm{X}$ et al. Immediate psychological responses and associated factors during the initial stage of the 2019 coronavirus disease (COVID-19) epidemic among the general population in china. International Journal of Environmental Research and Public Health. 2020; 17(5):1729

23. Qiu J, Shen B, Zhao M et al. A nationwide survey of psychological distress among Chinese people in the COVID-19 epidemic: implications and policy recommendations. General Psychiatry. 2020; 33(2): e100213.

24. Wang G, Zhang Y, Zhao J, et al. Mitigate the effects of home confinement on children during the COVID-19 outbreak. The Lancet. 2020; 395(10228):945-7.

25. Chan AH, Rutter V, Ashiru-Oredope $D$ et al. Together we unite: the role of the Commonwealth in achieving universal health coverage 
through pharmaceutical care amidst the COVID-19 pandemic. Journal of Pharmaceutical Policy and Practice. 2020; 13:1-7.

26. Cadogan CA, Hughes CM. On the frontline against COVID-19: Community pharmacists' contribution during a public health crisis. Res Social Adm Pharm. 2021; 17(1):2032-5.

27. Unadkat S, Farquhar M. Doctors' wellbeing: Self-care during the covid-19 pandemic. British Medical Journal. 2020; 368:m1150.

28. Alqrache AT, Mostafa MM, Atta HM. Knowledge and Attitude towards COVID-19 among students of King Abdul Aziz University. Era's J Med Res. 2020; 7(11):1-9.

29. Sohaira R, Madan H, Madan V et al. Knowledge, Attitude and practice among Medical and Non Medical students in Karachi, PakistanA comparative cross sectional study. iMed Pub. 2020; 12(5):1-6.

30. Ferdous MZ, Islam MS, Sikder MT et al. Knowledge, attitude, and practice regarding COVID-19 outbreak in Bangladesh: An online-based cross-sectional study. PLoS One. 2020; 15(10): e0239254. 